\title{
DA ORDEM MÍTICA AO “CAOS ENFEITIÇADO": O HOMEM E O MUNDO NA ODISSÉIA DE HOMERO E EM MOBY DICK, DE HERMAN MELVILIE
}

\author{
From mitic order to "chaos bewitched": \\ the man and the world in Odissea by Homero and in \\ Moby Dick by Herman Melville
}

Ravel Paz ${ }^{1}$

\section{Resumo}

O trabalho propõe uma aproximação entre a Odisséia e Moby Dick, sublinhando os traços épicos e míticos do romance de Melville em sua dialética com as contradições e o desencantamento de seu tempo.

Palavras-chave: Romance e epopéia; Mito e realidade; Desencantamento do mundo.

\section{Abstract}

This paper proposes a aproximation between Odissea and Moby Dick, emphasizing the epic and mitic features of Melville's novel in its dialetic with contradictions and disenchantment of its time.

Keywords: romance and epopee; myth and reality; disenchantment of the world.

1 Unicamp. E-mail: ravelgp@yahoo.com.br 


\section{Introdução}

Aproximar um romance moderno como Moby Dick, considerado a obra-prima do escritor norte-americano Herman Melville, de uma epopéia clássica como a Odisséia de Homero é um tipo de exercício comparativo que pede alguns esclarecimentos. Antes de mais nada, convém indicar que vínculos podem unir duas obras de origens tão distantes no tempo e no espaço. ${ }^{2}$ Esses vínculos, ou pelo menos os que dizem respeito a nossos objetivos, naturalmente relacionam-se à própria natureza da epopéia, ou seja, ao fato de Moby Dick ser um romance que contém características que podem ser consideradas épicas, como o impulso aventureiro, aliado a um certo espírito belicoso, e a celebração das glórias do universo narrado, sem falar em suas proporções monumentais. ${ }^{3}$ Ao mesmo tempo, esses elementos - inclusive o último deles, pois há no livro de Melville algo de um monumen to ruinoso - são aqui marcados por contradições alheias ao poema homérico, de modo que também é preciso, já de saída, assinalar pelo menos alguns pontos que distinguem essas obras. Afinal, Moby Dick é um romance escrito num contexto de crescente desencantamento e que exprime, consciente ou inconscientemente, esse processo, ligando-se - ainda que de modo algum conformando-se - àquele prosaísmo da vida moderna que Hegel já assinalava. Ele não está de modo algum, por exemplo, imune a uma noção que Lukács apontou, justamente em oposição à epopéia, como um dos dados constitutivos do romance moderno: a temporalidade. ${ }^{4}$ E como toda narrativa moderna que aspira a um autêntico espírito épico, pela própria natureza irrealizável dessa aspiração Moby Dick está também atravessada por um sentimento trágico da vida. Além disso, a "ordem mítica" a que ela mais diretamente se reporta, com cujos valores se defronta e a partir da qual constrói sua simbologia, não é a da mitologia grega, e sim a da judaico-cristã. Isso, como veremos, é determinante, já que noções como as de Mal e Absoluto atravessam toda a obra - mas também se atravessam mutuamente e são atravessadas por outros elementos em seu interior.

No entanto, nada disso impede que Moby Dick se nutra, pelo menos parcialmente, de algo a que se pode denominar um autêntico impulso épico. Um impulso ao qual talvez estejam diretamente ligadas algumas peculiaridades quase sem- pre mal compreendidas desse romance, como suas descrições minuciosas e sua profusão de citações e "discussões" científicas, históricas, filosóficas e artísticas sobre tudo o que se relaciona às baleias e aos navios baleeiros. Mais do que simplesmente conferir verossimilhança à narrativa, ${ }^{5}$ essas passagens parecem ter em vista justamente aquela celebração do universo narrado, característica das narrativas épicas. Aquilo que em Homero se constitui pela incorporação de episódios míticos e lendários legados pela tradição, no romance de Melville se realiza pela incorporação do conhecimento enciclopédico. Algo assim também está relacionado a sua assimilação dos mais variados estilos discursivos e gêneros literários. ${ }^{6}$ Nesse sentido, Moby Dick é também, de certa forma, uma celebração monumental da arte, da ciência e dos mitos, ainda que uma celebração problemática - mas também problematizadora, pois não raro se voltando contra o objeto de seu canto, quer seja "polemizando" com ele ou pela apropriação irônica - , erigida na solidão e clamando contra o silêncio do mundo.

Finalmente, é o próprio Melville quem relaciona, em mais de um momento e de modo privilegiado, essa atividade que lhe forneceu o motivo de seu canto - a caça à baleia - ao universo mítico da Antiguidade Grega. Vale a pena reproduzir uma dessas passagens - justamente a que abre um capítulo intitulado "A honra e a glória de apanhar baleia" -, não só porque ela constitui uma das mais belas do romance como porque deixa entrever, desde já, algo da complexa natureza de seu epos:

O valente Perseu, um dos filhos de Júpiter, foi o mais antigo baleeiro; e diga-se, para honra eterna de nossa profissão, que a primeira baleia atacada por nossa fraternidade não foi morta por nenhum egoístico. Foram estes os dias cavalheirescos de nossa atividade, quando empunhávamos armas apenas para socorrer os aflitos e não para encher as almotolias dos homens. Todos conhecem a bela história de Perseu e Andrômeda; de como a encantadora Andrômeda, filha de um rei, foi presa a um rochedo no litoral e de como, quando o Leviatã estava a arrebatá-la, Perseu, o príncipe dos baleeiros, avançou intrépido e arpoou o monstro, libertando a moça, com a qual se casou. Foi uma rara façanha artística, raramente levada a cabo pelos melhores arpoadores atuais, ainda mais que o Leviatã foi morto no primeiro arremesso. (MELVILLE, 1972, p. 433) 
A despeito de sua imperfeição constitutiva, tantas vezes apontada pelos críticos - mas também, de certa forma, graças a ela - , Moby Dick é sem dúvida uma obra ímpar. E a dialética de seu impulso épico com o espírito de seu tempo certamente ainda é capaz de nos revelar muito sobre nosso próprio mundo, e quem sabe até mesmo nos comunicar um pouco daquelas "experiências válidas" que, segundo Walter Benjamin, constituem uma das razões de ser das autênticas narrativas.

\section{O mundo e o lar, o caos e o cosmos}

Há uma ambigüidade fulcral na viagem de retorno de Odisseu a Ítaca, principal assunto da Odisséia: de um lado as saudades que o herói tem do lar e de outro seu anseio por viver mais aventuras, acumulando histórias e presentes e, ao mesmo tempo, vencendo as provações que lhes são impostas pelos deuses. Mas essa oposição, como todas as que informam o mundo homérico, deve de fato ser posta em termos de ambigüidade: de pólos, ou, antes, elementos que, embora sem excluir a conflituosidade, convivem de forma essencialmente não-contraditória, ou seja, alheia a qualquer cisão nos fundamentos ideológicos e existenciais que os sustentam: ${ }^{7}$ Odisseu é tão capaz de derramar lágrimas de saudades por seu "solar de alto teto", de declarar comovido que "eu cá não consigo ver nada mais doce que a terra da gente" quanto de contar que passou um ano inteiro banqueteando-se "de carne abundante e de vinho suave" à mesa e compartilhando do leito de Circe (HOMERO, 1996, p. 101).

Entretanto, se não é conveniente que se retorne à casa sem ter acumulado aventuras e experiências, a idéia do não-retorno é inaceitável. Diversos episódios, como o das sereias, dos lotófagos e o da própria Circe dão uma demonstração clara disso. Assim, quando passa pela ilha das sereias, Odisseu não se priva de se deleitar com seu canto, mas toma todas as precauções necessárias, recomendadas por Circe, para que tanto ele quanto seus guerreiros estejam a salvo de seu poder encantatório (HOMERO, 1996, p. 144-145). Quando, depois de provar do fruto do loto, alguns guerreiros já não querem "trazer notícias nem regressar, mas sim ficar ali com os lotófogos, sustentando-se de loto, sem pensar no regresso", o herói os traz à força e os amarra aos navios, ordenando em seguida que os demais embarquem logo, "para que nenhum, comendo loto, viesse a esquecer o regresso" (HOMERO, 1996, p. 103). Esquecer-se do retorno e das origens significa condenar-se a si próprio ao esquecimento, ou mesmo perder a condição humana: é o que quase ocorre com os guerreiros atraídos pelos encantos de Circe e por ela transformados em porcos, também estes salvos pelo herói (HOMERO, 1996, p. 118-122). O mesmo se dá no embate com a morte ou com as forças caóticas da natureza, expresso em episódios como os da passagem pelo Hades, pela ilha do Cíclope e pelos rochedos de Cila e Caribdis: são experiências válidas em si mesmas, inclusive em seu aspecto terrífico, mas que devem permitir o retorno do herói ao universo da ordem doméstica.

Há, portanto, no âmago desse duplo impulso, uma unidade entre a vida cotidiana, ou seja, a vida em Ítaca, e a vida no mundo mais amplo em que se dão as aventuras. Essa unidade é constitutiva do espírito da epopéia clássica, e se estabelece nos vários níveis do mundo homérico, inclusive no plano da relação dos homens com os deuses. Não que cotidiano e aventuras se equivalham, mas de certa forma se complementam, assim como, num outro plano, homens e deuses não são a mesma coisa, mas se relacionam a todo momento e têm diversos traços em comum. Assim, se por um lado Odisseu não gostava "da lavoura e do trabalho caseiro, que sustentam prole magnífica", preferindo "os barcos movidos a remo, as pelejas, as lanças polidas e as flechas, coisas lôbregas que aos outros causam horror" (HOMERO, 1996, p. 167), por outro não cessa de fazer paralelos entre suas ações e de seus homens com aqueles ou outros trabalhos cotidianos, como quando compara sua alegria pela chegada do pôr-do-sol e, em vista disso, da hora de seu retorno a Ítaca sob a escolta dos feácios, com a alegria do lavrador diante do "declínio da luz do sol, que traz a hora da ceia" depois "que a junta de bois cor de vinho puxou a ajustada charrua o dia inteiro no alqueire" (idem, 152-153). No mundo homérico, as ações humanas se refletem mutuamente (o que não significa que anulem sua diversidade): cada ato comunica seu sentido pleno, sua dignidade humana, à totalidade da vida; e é essa dignidade que é celebrada no mito, no qual a própria ordem cósmica instituída pela soberania dos deuses olímpicos e os atos destes 
tornam-se espelhos da realidade humana (o que não significa que se reduzam a ela).

Daí a Odisséia, embora constituindo principalmente o relato das aventuras de um único homem, ser um canto coletivo: as glórias e provações do herói são também glórias e provações dos aqueus. E daí sua aventura se revestir, notadamente no final, de um sentido a que, com o perdão do anacronismo ${ }^{8}$ se pode denominar político. O retorno de Odisseu não está relacionado apenas à necessidade de matar suas saudades, mas, sobretudo, à de restaurar a ordem em Ítaca; e isso implica não só em expulsar os "arrogantes pretendentes" à mão de Penélope de sua própria casa como também em restituir o respeito às tradições em toda a ilha. A imagem mais clara do desprezo que ameaça envolver essas tradições é o debate, travado na Assembléia convocada por Telêmaco para expulsar os intrusos da casa de seu pai, entre "o bravo ancião Haliterses, (...), que sobrepujava os coevos na ciência dos augúrios e emissão de vaticínios" e o pretendente Eurímaco. Interpretando a luta e a morte de duas águias nos céus de Ítaca, 0 ancião vaticina 0 retorno de Odisseu e a destruição dos pretendentes, tentando convencê-los a deixar o lar do herói. Haliterses é, porém, rechaçado por Eurímaco, que se diz mais capaz de interpretar os augúrios e lhe faz uma outra "predição":

se tu, apesar de teu velho e abundante saber, excitares este mocinho à cólera com teus conselhos, em nada poderá fazer a estes homens, e a ti, velho, aplicaremos uma multa que te doerá na alma pagar e duro será teu sofrimento (HOMERO, 1996, p. 23.).

Pouco depois, sob as exortações de outro pretendente, a Assembléia se dissolve. É esta situação, em que jovens ambiciosos e inexperientes pretendem sobrepujar quase pela força os sinais divinos e a sabedoria dos anciões, e, portanto, em que a unidade mítico-política do mundo está ameaçada de se romper, que terá fim com 0 retorno de Odisseu. Há no final da Odisséia uma espécie de ritual de gestos paradigmáticos, que parecem refletir a imagem dos vários níveis em que aquela unidade é reafirmada ou restaurada. $\mathrm{O}$ primeiro desses gestos é o do pai de Odisseu, o velho Laertes, que, revigorado em suas energias perdidas na ausência do filho e com a devida inspiração divina de Atena, arremessa a lança que mata Eupites, líder dos itacenses em busca de vingança pelo massacre dos pretendentes, pouco antes levado a cabo por Odisseu. Em seguida, este e seu filho, Telêmaco, lançam-se à batalha, enquanto Atena tenta contê-la. O herói, no entanto, reúne suas forças e, com um "brado terrível", arremete "como uma águia de alto vôo" contra seus adversários. Mas então o próprio Zeus intervém para evitar "uma guerra funesta para ambos os lados" e a batalha é definitivamente suspensa, selando-se "um juramento de paz para o futuro" entre os contendores (HOMERO, 1996, p. 288-289.). Assim, os gestos de Laertes, Odisseu e Telêmaco celebram a vitória da tradição e asseguram sua continuidade entre as gerações; o desafio de Odisseu ao apelo de Atena reafirma a restituição de sua autoridade na ilha; quanto à intervenção de Zeus, longe de constituir um índice negativo para o herói - prova disso é sua alegria após a advertência divina -, sinaliza que seu objetivo já foi cumprido e a ordem plenamente restaurada, e que, portanto, não é preciso ir mais longe.

Nada disso, porém, teria sido possível sem que Odisseu tivesse mais uma vez conquistado o reconhecimento por sua bravura em suas aventuras. E, ao final da epopéia, o herói aguarda ainda novas aventuras, mas também um novo retorno, para, num dia indeterminado, morrer e ser sepultado em sua ilha após eternizar seu nome, e o de seu povo, entre os homens e os deuses.

\section{O "Pequod": uma viagem sem volta}

Diversas passagens de Moby Dick podem fornecer contrapontos quase exatos aos temas e ao espírito da Odisséia. É claro que não reside aí qualquer intencionalidade de Melville nesse sentido, pois, a despeito dele obviamente conhecer Homero e realmente buscar fazer de seu romance uma espécie de epopéia, esses contrapontos, que naturalmente pressupõem pontos de contato, dizem respeito menos a semelhanças ou diferenças de episódios e personagens do que a identidades conflituosas de raízes mais profundas. Ainda que seja inevitável comparar o capitão $\mathrm{Acab}^{9}$ a Odisseu, e seja por meio dessa comparação que, de fato, as diferenças que queremos assinalar fiquem mais nítidas, não é absolutamente no plano da composição dos personagens que residem tais raízes. Elas nascem da própria relação do "impulso 
épico" que imprime força à narrativa com o solo do mundo narrado. Aliás, a palavra "solo", aqui, já nos remete ao centro da questão. Pois é justamente de uma oposição entre o mar e a terra que se nutre aquele impulso, como testemunham as primeiras palavras do narrador-personagem (não propriamente protagonista, mas também pouco mais do que um mero observador) Ismael:

Chamai-me Ismael. Faz alguns anos - não importa quantos, precisamente -, tendo na bolsa escasso ou nenhum dinheiro e nada que particularmente me interessasse em terra, achei que devia velejar um pouco e ver a parte aquosa do mundo. É um hábito que eu tenho, para acabar com o esplim (spleen) e regular a circulação. Sempre que começo a ficar austero; sempre que é um novembro úmido e chuvoso em minha alma; sempre que dou comigo a parar involuntariamente diante de empresas funerárias e a cerrar fila em cada enterro que encontro; e especialmente sempre que minha hipocondria adquire tal domínio sobre mim que é preciso um sólido princípio moral para impedir-me de sair deliberadamente para a rua e metodicamente surrar as pessoas - então acho que está na hora de ir para o mar o mais depressa possível (MELVILLE, 1972, p. 25.).

Como se vê, o mundo de origem, o mundo social, das convenções, e o espaço das aventuras estabelecem aqui uma relação radicalmente diferente da que se dava na Odisséia, uma relação que não pode mais ser compreendida em termos de ambigüidade, e sim de contradição. O "mundo terrestre" é descrito como um território estagnado, cujos habitantes vivem uma espécie de morte em vida; e o fato de um pouco adiante Ismael dizer que "Quase todos os homens (...), qualquer que seja a sua classe, uma vez ou outra compartilham comigo quase que os mesmos sentimentos para com o oceano" não atenua em nada essa situação: antes a agrava, na medida em que universaliza o mal-estar. Imagem ainda mais evidente desse malestar é aquela contida na figura do "sub-sub-bibliotecário" que fornecera ao narrador as citações dispostas no início do livro, personagem que, apesar de "diligente, cavalador e laborioso", é definido como um ser pertencente "àquela tribo incurável e pálida que vinho algum deste mundo jamais aquecerá e para a qual mesmo o branco xerez seria excessivamente rosado e forte" (MELVILLE,
1972, p. 13). Quanto ao mar, e à água de um modo geral, Ismael lhes dedica as próximas páginas, procurando comprovar a grandeza de seu mistério, numa extensa argumentação que termina assim:

Por que os antigos persas consideravam sagrado o mar? Por que lhe atribuíam os gregos um deus especial, o próprio irmão de Jove? Por certo tudo isso não deixa de ter sentido. E ainda é mais profundo o sentido daquela história de Narciso, que, por não poder pegar a imagem, atormentadora e suave, que ele via na fonte, mergulhou nela e afogou-se. Mas essa imagem, nós mesmos a vemos em todos os rios e oceanos. É a imagem do inagarrável fantasma da vida; e esta é a chave de tudo (MELVILLE, 1972, p. 27.).

Dessa concessão ao mar de um sentido singularíssimo, por vezes mesmo metafísico, é que nascerá a peculiaridade da "celebração épica" de Moby Dick, uma celebração fundada justamente na demarcação de um espaço de exceção, na reivindicação de uma espécie de privilégio. Assim, por exemplo, o narrador reserva um capítulo inteiro, intitulado "O advogado", para comprovar a dignidade da atividade baleeira; mais do que realizar tal objetivo, porém, ele culmina por investir essa atividade de um sentido quase absoluto, vendo-a não apenas como algo grandioso, mas como uma espécie de sucedâneo privilegiado da vida:

Não há dignidade na profissão de baleeiro? A dignidade de nossa ocupação o próprio céu a atesta. (...) Conheço um homem que, em toda a vida, apanhou trezentos e cinqüenta baleias. Considero esse homem mais digno de honras do que aquele grande capitão da antiguidade que se vangloriava de ter tomado o mesmo número de cidades fortificadas.

Quanto a mim, se por alguma contingência, ainda tiver algo de excelente escondido em meu íntimo; se existe alguma reputação neste pequeno, mas altamente silencioso mundo, à qual, não imerecidamente, eu possa aspirar; (...) atribuo toda a honra e toda glória disso à atividade baleeira: pois num navio baleeiro tive as minhas Universidades de Yale e Harvard. (MELVILLE, 1972, p. 146-147; à exceção da primeira frase, os demais grifos sãos nossos.)

E se Ismael reserva elogios à cidade, ou melhor, ao porto e aos homens de Nantucket, é 
tão somente porque este se trata de um lugar que, segundo uma anedota contada com indisfarçável orgulho, o mar "fecha, cinge, cerca, envolve e ilha tão completamente, que em suas próprias cadeiras e mesas poderão encontrar-se de vez em quando pequenos mariscos grudados", um lugar cujos homens "residem e se amotinam no mar (...). Lá está sua atividade, que um dilúvio de Noé não interromperia, embora submergisse os milhões de habitantes da China" (MELVILLE, 1972, p. 92-94; grifo do autor).

Tudo isso é bastante estranho ao universo da epopéia grega. Afinal, para Odisseu não há nenhum problema se "os gostos não são iguais" (HOMERO, 1996, p. 167): ainda que suas glórias sejam maiores que as de quaisquer itacenses, elas são extensivas a todos eles; e o mar, a despeito de todos os seus mistérios e desafios, é como que um prolongamento da vida cotidiana, enquanto para Ismael as glórias nele conquistadas e a vida do "silencioso mundo" cotidiano estão fundamentalmente dissociadas. No entanto, já vimos que a "chave" de Ismael é uma chave partida, pois tampouco ela pode deixar de refletir a cisão entre a existência e seus fundamentos existenciais, que ele mesmo reconhece na vida moderna. Como deixa entrever a relação estabelecida com o mito de Narciso, também o mar está ligado, em Moby Dick, a uma pulsão de morte; e mesmo refletida nele, a vida continua sendo fantasmagórica, "inagarrável".

Daí que, mesmo em alto mar, aquele "solo" não se desvaneça, e é dessa indissociabilidade que nascem as tensões fundamentais de Moby Dick, e com elas a condição trágica de seu verdadeiro protagonista: o velho capitão Acab. É possível ver Acab quase como uma antítese dos heróis homéricos. Imagem da misantropia e do desprezo pelo mundo, a ponto de não travar conhecimento com os próprios marinheiros uma única vez antes da partida do navio, o comandante do "Pequod" é movido exclusivamente por um desejo obsessivo: matar Moby Dick, o grande cachalote branco que lhe decepara uma perna. Tal "obsessão monomaníaca” é, evidentemente, diametralmente oposta ao espírito da Odisséia. É certo que o herói de Homero leva sua vingança contra os pretendentes até 0 fim, mas nem por isso se apressa em consumá-la, nem deixa de participar dos banquetes de seus inimigos, agüentando "de coração paciente os projéteis e insultos em seu próprio solar" (HOMERO, 1996, p. 280). Além disso, enquanto o he- rói de Homero zela por seus companheiros e procura conduzi-los consigo para casa, Acab leva a todos, e não inconscientemente, para uma viagem sem volta. E ainda que os caprichos (mas não obsessões) de Odisseu sejam responsáveis - principalmente no episódio do Cíclope - pela morte de pelo menos alguns guerreiros, tampouco aí o equilíbrio se rompe: não só Odisseu se redime, na medida em que "excogitava a melhor maneira possível de salvar meus camaradas e a mim próprio da morte", como os sobreviventes prosseguem a viagem "de coração pesaroso, mas contentes de escapar à morte, embora com a perda de companheiros queridos" (HOMERO, 1996, p. 110). É, sobretudo essa possibilidade sempre renovada de se reinstaurar um equilíbrio, ora de um, ora de outro lado, que está definitivamente excluída de Moby Dick: aqui a lei predominante não é a das compensações, mas das oposições inconciliáveis.

Talvez a viagem de Telêmaco em busca do pai constitua o exemplo mais esclarecedor do sentido da experiência no poema de Homero. Tratase de uma viagem aparentemente infrutífera, na medida em que Telêmaco não chega sequer a obter notícias concretas de Odisseu. No entanto, sua breve aventura é bem sucedida no sentido de que, através dela, ele acumula honras e presentes, e, sobretudo, começa desde já a glorificar seu nome. Para Acab, porém, não importam honras, riquezas nem o apreço dos homens, mas tão somente alcançar seu objetivo. Ainda que o arrebatem saudades do lar distante - afinal, ele acabara de se casar e ter um filho, quando foi mutilado pela baleia -, jamais isso seria suficiente para demovê-lo desse objetivo. Em uma determinada passagem, transcorrida num dia cuja beleza o comove, o capitão resume suas desventuras para o imediato Starbuck: fala no "isolamento murado, de cidade fortificada" que tem sido sua vida, e também sobre a "juvenil esposa", que deixara como a "uma viúva com o marido vivo" para se dedicar, com "loucura, frenesi, o sangue a ferver e a testa a fumegar", à caça de Moby Dick, terminando, num acesso de comoção, por pedir ao imediato que se poupe do enfrentamento com a baleia; ao que este lhe responde:

-- Oh, meu capitão, meu capitão, nobre alma! grande e velho coração, apesar de tudo! por que tem qualquer homem de dar caça a esse odiado peixe? Vem comigo! Fujamos destas 
águas mortais! vamos para casa! Mulher e filho, também Starbuck os possui, mulher e filho de sua juventude fraternal, sorória, companheira de folguedos, exatamente como os teus, senhor, são a mulher e o filho de tua velhice amante, ardente, paternal! Embora! vamos embora! Deixa-me alterar a rota agora mesmo! Que animados, que alegres, ó meu capitão, haveríamos de rodar em nosso caminho para ver a velha Nantucket de novo! Acho, senhor, que há certos dias suaves e azuis como este em Nantucket! (MELVILLE, 1972, p. 631-632.).

Acab, porém, não pode atender ao apelo de seu companheiro; num gesto de impotência, agitando-se "como uma árvore frutífera seca", ele se lamenta:

-- Que é, que coisa indizível, inescrutável, sobrenatural; que falacioso, oculto senhor e amo, e cruel, desumano imperador dispõe de mim (...)? Sou eu, ó Deus, ou quem é que ergue este braço? Pelo céu, homem, somos girados e regirados neste mundo, como aquele cabrestante, e o Destino é a alavanca... (MELVILLE, 1972, p. 631-632.).

Passagens como essas revelam o quanto a "epopéia" de Melville é atravessada por um sentido trágico. Na verdade, Acab não chega a ser portador de um "espírito aventureiro". Tal espírito é encarnado, sobretudo pelo próprio narrador, Ismael, além do selvagem Quiqueg. O paradoxo, no entanto, consiste justamente no fato de que somente Acab tem magnitude suficiente para alçar a relação dos homens com o universo a que Melville quer dar forma a uma grandiosidade épica uma grandiosidade, portanto, que só pode ser simultânea e paradoxalmente trágica. Embora seja Ismael, mais do que o próprio Acab, quem enxergue uma cisão irreconciliável entre o homem e 0 mundo, ele não mergulha nela plenamente, pois em nada seu espírito aventureiro o predispõe a isso: antes, lhe serve de alívio, como se reconhece no parágrafo inicial da narrativa; e, afinal, conforme atesta outro trecho já citado, o jovem marinheiro ainda aspira a "alguma reputação neste pequeno, mas altamente silencioso mundo".

Mas se Acab, ele próprio cindido no corpo e na alma, é o único capaz de mergulhar nas profundezas das contradições desse mundo, enquanto Ismael é, sobretudo, o "aedo" dessas contradições - mas também, quem sabe, aquele ca- paz de extrair delas algum aprendizado -, nem os sentidos mais profundos que Melville buscou imprimir a sua obra nem aqueles que talvez escapem a sua própria intenção podem ser desvelados sem antes nos determos sobre aquele elemento que constitui o núcleo simbólico do romance: a própria Moby Dick.

\section{Moby Dick e o "caos enfeitiçado"}

De todas as interpretações passíveis de serem extraídas desse "personagem" formidável que é Moby Dick, sem dúvida a mais simplista é aquela, familiar às apostilas didáticas, ${ }^{10}$ que 0 vê como a encarnação do Mal. Não que tal leitura seja totalmente desprovida de fundamento: afinal, ela corresponde à visão que o próprio Acab tem da baleia. Como explica Ismael, o capitão "transferiu delirantemente" para ela a idéia daquela "impalpável malignidade que sempre existiu": "todo o mal, para o doido Acab, personificava-se visivelmente e podia praticamente ser atingido em Moby Dick" (MELVILLE, 1972, p. 228-229). Mas, como enfatiza o próprio narrador, isso constitui somente "o que o cachalote branco representava para Acab", e não para ele próprio e também, portanto, na totalidade da obra, já que o que está em jogo não é apenas a visão de Acab (MELVILLE, 1972, p. 233). Os sentidos que Ismael atribui a Moby Dick são muito mais complexos, e não há dúvida de que sem eles as dimensões mais profundas da tragicidade de Acab não podem ser compreendidas.

A "interpretação" do narrador gira principalmente em torno de uma característica da baleia que lhe desperta um "vago, inominável horror": sua brancura, à qual ele dedica um capítulo inteiro. Ao longo desse capítulo, Ismael procura expor os paradoxos que ele vê associados à cor branca. Apesar de ser símbolo e expressão privilegiada da beleza, da alegria, de tudo que "é doce, e honroso, e sublime", e da própria "pureza e da força divinas", do "próprio véu da Deidade Cristã", Ismael nos alerta que "esconde-se algo de enganador na mais secreta idéia dessa cor, a qual traz mais pânico à alma do que a vermelhidão que assusta no sangue". Mas em que consiste essa natureza terrivelmente enganadora, contida "na mais secreta idéia dessa cor"? É a interrogação a que o próprio narrador tenta responder ao final do capítulo: 
Será porque por sua indefinição ele [o "brancor"] representa os vazios e imensidades sem coração do universo, e assim nos apunhala por trás com o pensamento da aniquilação, quando contemplamos os brancos abismos da Via-Láctea? Ou será porque, no fundo, o branco não é bem uma cor, mas a ausência visível da cor, e ao mesmo tempo a suma de todas as cores; será por isso que há uma brancura muda e cheia de sentido numa paisagem nevosa - um descolorido, onicolor ateísmo ante o qual recuamos? E quando consideramos aquela outra teoria dos filósofos da natureza, segundo a qual todas as outras cores terrenas - toda decoração imponente ou encantadora -, os doces tons dos céus e florestas crepusculares; sim, e o dourado veludo das borboletas e as faces de borboleta das mocinhas, tudo isso não passa de sutis ilusões, não inerentes, na verdade, às substâncias, mas apenas impostas de fora, de modo tal que toda a natureza deificada se pinta como a prostituta, cujas seduções recobrem apenas o ossuário interior (...) - ao ponderarmos tudo isso, o universo paralisado estende-se à nossa frente como um leproso (...). De todas essas coisas o cachalote albino era o símbolo. Admirais-vos pois da furiosa caçada? (MELVILE, 1972, p. 243.).

Como se vê, aqui a simbologia de Moby Dick vai além daqueles termos definidos pela visão de Acab. Agora ela exprime o próprio paradoxo da existência, o medo da aniquilação absoluta, da dissolução do Ser no Nada, no "ossuário interior" recoberto pelas cores ilusórias da existência. Nesse sentido, a busca de Acab não remete apenas ao embate com o Mal, mas toca no niilismo absoluto. Afinal, mesmo o reino de Lúcifer não significa a aniquilação total. É somente num contexto de crise de uma visão de mundo onde as forças ordenadoras da existência sobrepõem-se de forma absoluta às caóticas - e não mais convivem com elas numa incessante dialética - , ou seja, a visão de mundo da teologia cristã, que esse movimento pode ser compreendido. Ameaçada de ser deposta de sua soberania absoluta, a ordem divina deixa entrever por trás de si não apenas o caos ou o Mal, que, desprovidos da essencialidade que lhes conferia essa mesma ordem, agora confinam com o Nada.

Mas a brancura da baleia é síntese, simultaneamente, do Nada e do Absoluto - "a ausência visível da cor, e ao mesmo tempo a suma de todas as cores" -, símbolo tanto do "universo paralisado" quanto do "próprio véu da Deidade Cristã". Ao mesmo tempo, a visão de Acab não pode ser simplesmente descartada dessa equação, onde, no fim das contas, parecem conviver elementos aparentemente díspares e inconciliáveis. De um lado, aqueles de fundo teológico ou ligados a uma metafísica da presença: o Destino, a Divindade e mesmo, a despeito de sua carga negativa, o Mal; de outro, um niilismo absoluto, ligado a um processo de desencantamento radical e que acaba configurando uma espécie de "metafísica da ausência". Elementos inconciliáveis, mas estranhamente intercambiáveis, surgindo-nos como que embaralhados. Nossa hipótese, porém, é que uma unidade dialética subjaz a esse "embaralhamento": uma dialética cuja síntese é sempre incompleta e cujos termos de fato permanecem inconciliáveis, mas que nem por isso deixam de constituir uma unidade, certamente contraditória, mas não incoerente. Mas em que se constituiria ela, afinal? Uma primorosa passagem localizada logo no terceiro capítulo do romance - quando Ismael, chegando a Nantucket à procura de trabalho num baleeiro, aloja-se numa certa "Estalagem da Baleia" - talvez possa nos indicar o caminho para a resposta. Nessa sua espécie de "primeira descida" ao mundo da caça à baleia, Ismael se depara, quase imediatamente, com

um vasto quadro a óleo, tão cabalmente sujo de fumaça e em todos os aspectos tão desfigurado, que, considerando-se a insuficiência das luzes cruzadas sob as quais era visto, apenas por meio de um estudo diligente e de uma série de sistemáticas inspeções, bem como de cuidadosas perguntas aos vizinhos, se poderia de algum modo atinar com o seu sentido. Tão inexplicável amontoado de escuros e sombreados quase nos fazia pensar, à primeira vista, que algum pintor, ambicioso e jovem, no tempo das bruxas da Nova Inglaterra, havia tentado representar o caos enfeitiçado. Mas, à força de muita e severa contemplação e de repetidas ponderações, e especialmente abrindo a janelinha do vestíbulo, chegava-se por fim à conclusão de que tal idéia, embora extravagante, podia não ser de todo descabida (MELVILLE, 1972, p. 35-36.).

"O caos enfeitiçado": ${ }^{11}$ por mais gratuita que essa expressão possa parecer, ela se insere num episódio cuja dimensão simbólica está muito 
bem assinalada. Quanto ao tom humorístico do último período, ele não deve nos enganar, mesmo porque em nada desmente o já dito. De qualquer forma, a análise de Ismael não termina aí, e logo em seguida ela nos revelará que

o quadro representava um navio sob um tufão no cabo Horn, vendo-se apenas os três mastros desguarnecidos da embarcação quase afundada, joguete das ondas, e uma baleia exasperada, tencionando saltar por cima do barco, na realidade estava cravando-se na ponta dos três mastros (MELVILLE, 1972, p. 36.).

Como se vê pela sua extravagância, a cena finalmente desvelada não nega aquela primeira interpretação: antes, parece realmente encontrar nela sua melhor tradução. Mas em que sentido essa expressão curiosa, "o caos enfeitiçado", pode nos ser útil? No sentido de que ela parece conter, em sua estrutura semântica, a estrutura simbólica através da qual Melville, consciente ou inconscientemente, buscou dar forma aos conflitos de seu romance. Estrutura esta que, em sua relação de subordinação do substantivo ao adjetivo, parece traduzir uma "metafísica do caos", ou seja, uma tentativa de investir o sentimento de uma desordem constitutiva do mundo, o sentimento de ausência de qualquer lógica a reger os destinos, de qualquer sentido imanente ou transcendente à vida, de uma configuração metafísica. A tentativa, em outras palavras, de fixar a imagem simbólica de algo que possa presidir à desordem do universo e que não seja simplesmente uma nova ordem. Para Acab, essa imagem não é outra senão Moby Dick, símbolo simultâneo do Nada e do Absoluto, da morte aniquiladora e do "fantasma inagarrável da vida" - mas sempre envolto pela idéia da malignidade, assim como o dilaceramento existencial de Acab está envolto pela idéia de Destino. ${ }^{12}$ É como se Melville tentasse assimilar o desencantamento de seu tempo aos esquemas teológicos que esse mesmo processo punha em xeque: sem dúvida, algo ideológica e "filosoficamente" problemático, mas também, pelo menos nesse caso particular, de inegável força artística.

De qualquer forma, ainda aqui é o mito que espelha o homem, e não o contrário, de modo que se quisermos completar esse quadro devemos agora retornar tanto aos tripulantes do "Pequod" quanto àquele solo, do qual em nenhum instante, até sua destruição final, o baleeiro se desprendeu totalmente.

\section{O Absoluto e a vida: entre o olhar de Acab e o de Ismael}

Se na Odisséia cada ato do herói parece se comunicar com seu mundo de origem, no universo de Moby Dick a "celebração épica" das ações de seus "heróis" e a totalidade da vida guardam uma distância verdadeiramente imensurável. Os termos do narrador em sua "defesa" da atividade baleeira são uma demonstração disso. De um lado, Ismael se vê diante da necessidade de legitimar tal atividade, defendendo-a do "desprezo dos homens de terra" e "da injustiça perpetrada contra nós, baleeiros", ao se julgar que "não há dignidade na atividade baleeira", e de outro compara a glória dessa profissão a um "confronto com os terrores e maravilhas de Deus", ou sustenta, por exemplo, que ela "gerou acontecimentos tão notáveis em si mesmos, e tão continuamente significativos, que a atividade baleeira pode ser comparada àquela mãe egípcia, que deu à luz criaturinhas prenhes" (MELVILLE, 1972, p. 144). Entre esses sentidos atribuídos à pesca à baleia e aquilo que o mundo reconhece nela há, portanto, um abismo. Entretanto, é na dimensão prática dessa atividade que se revela mais claramente tal distância. Afinal, pergunta-se Ismael, como é possível tanto desprezo "se temos uma frota de mais de setecentos navios, tripulada por dezoito mil homens (...) e trazendo para nossos portos um ultracompensador produto anual de sete milhões [de dólares]?" (MELVILLE, 1972, p. 143.).

A resposta só pode ser que o sentido da caça à baleia se reduziu, para os outros homens, quando muito ao seu aspecto utilitário, num contexto em que a utilidade e o sentido "humano" da práxis, sua dignidade intrínseca, encontram-se dissociados. Essa dissociação entre vida prática e moral é explícita, por exemplo, na caracterização de um dos sócios-proprietários do "Pequod", o religioso e sovina capitão Bildad:

Embora recusasse, por escrúpulos de consciência, tomar armas contra os invasores de terra, ele próprio invadira descompassadamente o Atlântico e o Pacífico; e, embora inimigo jurado do derramamento de sangue humano, vertera, com seu casaco justo, barris e barris do sangue de Leviatã. Como, no entardecer contemplativo de seus dias, o piedoso Bildad conciliava na lembrança essas coisas, não o sei; mas isso não parecia preocupá-lo muito, 
e provavelmente fazia tempo que chegara à sábia conclusão de que a religião de um homem é uma coisa, e a vida prática muito diferente. Este mundo paga dividendos(MELVILLE, 1972, p. 106.).

Também aqui é inevitável a comparação com a epopéia homérica, onde as glórias dos heróis recebiam sua justa recompensa tanto na aprovação dos deuses quanto nas riquezas ofertadas pelos homens. Note-se ainda que, no fim das contas, a contradição afeta o discurso do próprio narrador.

No entanto, é óbvio que essa condição problemática não é privilégio dos caçadores de baleia. Afinal, a mesma perda do sentido intrínseco a sua práxis, guardadas as devidas glórias e proporções, também marca aquele "pobre-diabo de sub-sub-sub bibliotecário, diligente, cavalador e laborioso", a quem Ismael faz a seguinte exortação: "D esisti, sub-subs! Pois quanto maiores sejam os vosso esforços para agradar ao mundo, tanto mais ficareis para sempre sem agradecimento!" (MELVILLE, 1972, p. 13.). E não é esta, de um certo modo, a condição do próprio Melville, que clama pelo reconhecimento de um "silencioso mundo" onde as narrativas, a experiência, o heroísmo e a cultura perdem progressivamente o valor? Aliás, o silêncio e aquela "queda de cotação" da experiência mais tarde apontada por Benjamin são características que ligam todos os níveis desse mundo. Eles estão presentes, por exemplo, no grupo de velhos pescadores aos quais Ismael se juntara na Estalagem da Baleia, na esperança de "ouvir boas histórias sobre pesca de baleia", mas que, para sua surpresa, conservaram-se em "profundo silêncio"; ou no cerrado mutismo em que se dão as refeições dos oficiais no camarote de Acab (MELVILLE, 1972, p. 57; 188-189). E se aquele universo esboçado por Ismael no início do livro parecia habitado por mortos-vivos, não é diferente a situação do capitão do "Pequod":

E, se tivésseis observado o rosto de Acab naquela noite, pensaríeis que também nele duas coisas estavam-se guerreando. Ao passo que sua perna viva provocava vivas ressonâncias no convés, cada passo de sua perna morta soava como uma pancada em caixão de defunto. O velho caminhava sobre vida e morte (MELVILIE, 1972, p. 287.).
Essa fantasmagoria, aliás, Acab terminará por impor à tripulação do navio:

Nesse intervalo prenunciador, também toda graça, postiça ou natural, despaareceu. Stubb não mais se esforçou por despertar um sorriso; Starbuck não mais se esforçou por reprimir algum. Alegria e tristeza, esperança e temor pareciam reduzir-se igualmente ao mais fino pó e triturar-se, naquelas circunstâncias, no gral abarrotado da alma de aço de Acab. Como autômatos, moviam-se mudamente pelo convés, sempre conscientes de que o olhar despótico do velho estava sobre eles. (MELVILLE, 1972, p. 622).

Também esses homens parecem mortosvivos, cerrando fila para seus próprios enterros.

Assim, por trás do universo aparentemente fechado do "Pequod", há todo um contexto social e histórico, onde qualquer unidade entre o homem e o mundo parece ausente, onde todos os valores parecem volúveis, inconsistentes, e a idéia de que uma ordem transcendente possa estar por trás deles, a guiar os desígnios humanos, torna-se cada vez menos plausível. São as contradições desse contexto de desencanto e desencantamento a que Melville tentou dar forma artística numa metafísica peculiar: a metafísica de um "caos enfeitiçado". O que distingue Acab dos demais habitantes desse mundo é que o velho capitão não só não se dispôs a suportar sua indiferença como, sobretudo, desistiu de clamar pelo seu reconhecimento, voltando-se para o delírio do Absoluto, em busca do "inagarrável fantasma da vida". Mas ao fazer do Absoluto seu único alvo, Acab se privou dos últimos vínculos que o ligavam à vida. Por isso, tudo aquilo que na epopéia constitui prova de apreço pela vida e pelas ações humanas é radicalmente excluído de seus atos. Um exemplo dramático é o encontro do "Pequod" com o baleeiro "Raquel", cujo capitão assistira o bote do filho ser arrastado por Moby Dick no dia anterior. Logo de início, o narrador - que, capítulos antes, havia descrito um "gam", ou seja, um "encontro social de dois (ou mais) navios baleeiros" - sublinha que, embora conhecidos, "nenhuma saudação foi trocada" entre os velhos pescadores (MELVILLE, 1972, p. 296). E quando o capitão do "Raquel" implora ao do "Pequod" que o ajude a encontrar o filho e os demais marujos desaparecidos, Acab mantémse "como uma bigorna, que recebe todos os gol- 
pes sem o mínimo tremor" (MELVILLE, 1972, p. 616-618). Desnecessário sublinhar o contraste com as cerimônias de acolhimento na Odisséia quando, por exemplo, Telêmaco viaja em busca do pai.

No universo de Moby Dick, a práxis não une, mas aparta os homens. E apartado da vida, tendo como único horizonte um Absoluto que se confunde com a aniquilação, Acab não poderia ter outro destino senão o completo e definitivo silenciamento:

O arpão foi atirado; a baleia ferida voou para frente; com velocidade ignescente a arpoeira correu pela ranhura; correu emaranhada. Acab inclinou-se para desembaraçá-la; conseguiuo; mas a volta que voava apanhou-o pelo pescoço, e, calado como os mudos turcos estrangulam sua vítima, foi arremessado do bote, antes que a equipagem percebesse que ele se tinha ido. Logo a seguir o pesado laço da extremidade final da arpoeira voou da tina completamente vazia, derrubou um remeiro, e atingindo o mar desapareceu em suas profundezas (MELVILLE, 1972, p. 666.).

Mas se a morte silenciosa de Acab e o naufrágio do "Pequod" são as últimas cenas do drama de Moby Dick, não o são de sua epopéia. Ismael, aquele que, como o servo de Jó, escapou para contar a história, nos lembra que o olhar de Acab não é o único a incindir sobre esse mar tumultuoso. Este é um olhar que reduz tudo a si mesmo e a suas próprias obsessões - o que o próprio Acab reconhece, por exemplo em sua "interpretação" da gravura de um dobrão de ouro que ele mesmo pregara no mastro do navio como recompensa para o marinheiro que primeiro avistasse Moby Dick:

"Há sempre algo de egoístico nos cumes e torres, e em todas as outras coisas imponentes e altaneiras; vêde aqui: três píncaros tão soberbos como Lúcifer. A firme torre é Acab; o vulcão é Acab; a ave corajosa, intrépida e triunfante é Acab, também ela é Acab; todos são Acab..." (MELVILLE, 1972, p. 510.).

Se o "valente Perseu", aquele "primeiro baleeiro", não era "nenhum egoístico", Acab é a própria imagem do egocentrismo.

No entanto, ao olhar de Acab contrapõese 0 do próprio narrador, que, não obstante muitas vezes se confunda com o primeiro, certamente alarga-se para muito além dele. É sobretudo para o dinamismo e a multiplicidade da vida que o olhar de Ismael se dirige. Aquela vida intensa e feroz no interior do "Pequod" lhe fornece matéria para um dos mais curiosos capítulos de Moby Dick, aquele em que um verdadeiro carnaval se celebra no navio sob o ritmo do pandeiro do pequeno Semente-de-Maçã (personagem, aliás, mais tarde reduzido a um sinistro vulto de Acab). Nesse capítulo,, ${ }^{13}$ 0 narrador cede lugar a marujos das nacionalidades mais díspares - uma tripulação, como ele dirá mais adiante, "constituída principalmente de mestiços renegados, de párias e canibais" (MELVILLE, 1972, p. 232) -, tentando conferir particularidade cultural a seus discursos. Por mais caricatural que seja o resultado, ele não elide o fato de que Moby Dick é também uma espécie de epopéia dialógica, onde o narrador, ao longo de todo o livro, dá voz a dezenas de "guerreiros" que participam dela.

São esses "canibais", esses "nobres selvagens" (MELVILE, 1972, p. 191) - os arpoadores do "Pequod" -, que rompem com o obsessivo silêncio das refeições no camarote de Acab, comendo "como lordes", mastigando "o alimento com tanto gosto, que isso proclamava que estavam à mesa" (MELVILLE, 1972, p. 190). E é justamente, e um tanto paradoxalmente, um desses canibais 0 personagem que mais se aproxima, em espírito, de Odisseu em todo o romance de Melville: 0 arpoador e empalhador de cabeças Quiqueg, com quem Ismael partilha sua cama na Estalagem da Baleia e de quem se faz, à maneira de Aquiles e Pátroclo na Ilíada, "amigo íntimo". Somente Quiqueg, do alto de sua inocência pagã, alia o espírito aventureiro, o heroísmo, a nobreza ingênua e o vigor físico de um herói homérico.

É com Quiqueg que aquele "descentramento" espiritual a que tampouco Ismael está imune pode tomar, para este, um sentido positivo, assumindo a forma de possibilidade de compreensão do outro. É claro que a configuração dessa alteridade não é propriamente uma aula de antropologia: pelo contrário, Quiqueg é marcadamente ideologizado; no entanto, há sem dúvida - ainda mais em plena metade do século XIX - uma nova disposição face ao outro contida num episódio como aquele em que Ismael aceita participar do culto e oferecer pequenas "hecatombes" ao deus Yojo (MELVILLE, 1972, p. 82); ou, mais ainda, naquele em que o selvagem narra duas histórias que mostram o quão relativas são as noções de ridículo em cada cultura (MELVILLE, 1972, p. 88-89). 
E esta - é preciso sublinhar - é sem dúvida uma disposição que nasce do impulso épico de Moby Dick, de sua necessidade de buscar o motivo do canto na própria imanência da vida; uma necessidade que, não podendo ser satisfeita nos limites de um mundo onde os vínculos profundos com a vida parecem ter se dissolvido, projeta-se sobre outras culturas. É ao lado de Quiqueg que Ismael, após participar do culto ao seu ídolo pagão, partilhar de seu cachimbo, ser por ele presenteado, dormir e acordar a seu lado, experimenta aquilo que Acab estava fadado a jamais alcançar em sua busca do Absoluto, ou seja, a sensação de estar plenamente vivo:

Sentíamo-nos otimamente bem e abrigados, tanto mais que fazia muito frio lá fora; na verdade também fora das cobertas, porque não havia lareira no quarto. Tanto mais, eu digo, porque em verdade, para desfrutar o calor do corpo, alguma pequena parte dele deve estar fria, pois não há qualidade neste mundo que não seja o que é meramente por contraste. Nada existe por si mesmo (MELVILE, 1972, p. 83.).

Essa dialética, que não é apenas do frio e do calor, mas também das relações e diferenças culturais e intersubjetivas, seria incompreensível para Acab, para quem a circunferência deve ser fiel ao centro e somente "o semelhante cura o semelhante" (MELVILLE, 1972, p. 620). Em sua desordenada esfera, ou em seu caos encantado, a vida já não se reduz à pulsão de morte, mas, pelo contrário, abriga-se - não, é claro, sem um sutil sacrificialismo no seio da própria morte: é graças ao caixão que certa vez Quiqueg, padecendo de uma febre aparentemente fatal, mandara construir a fim de chegar às estrelas de seu mundo mítico, que Ismael, valendo-se da proteção de sabe-se lá que divindade, pode sobreviver para contar sua(s) história(s):

Tendo o caixão como bóia, sobrenadei quase um dia e uma noite, num mar suave como de elegia fúnebre. Os tubarões, inofensivos, deslizavam por ali como se tivessem cadeados nas bocas; os selvagens falcões do mar voavam de bicos embainhados. No segundo dia, um veleiro aproximou-se cada vez mais, e afinal me recolheu. Era o "Raquel", que cruzava fora de rota e que, retrocedendo a buscar seus filhos perdidos, achara apenas um outro órfão (MELVILLE, 1972, p. 668.).

\section{Notas}

2 Passando ao largo da chamada "questão homérica", é mais ou menos ponto pacífico que as grandes epopéias gregas - a Ilíada e a Odisséia - tomaram formas próximas às que chegaram até nós entre os séculos X e IX a.C., nas regiões da Eólia e da Jônia, embora reunindo materiais narrativos de outros períodos e lugares. Herman Melville nasceu em Nova York em 1819, e a primeira edição de Moby Dick data de 1851.

3 A edição utilizada, por exemplo, tem 668 páginas, onze delas ocupadas somente pelas oitenta e cinco "epígrafes".

4 Cf. Lukács (s/d, p. 142).

5 Como quer, por exemplo, Leon Howard, conhecido biógrafo de Melville, em seu artigo dedicado a Moby Dick no volume Panorama do romance americano (cf. HOWARD, 1966, p. 33).

6 Além de um hino e um sermão protestantes (capítulo IX, "O sermão"), Moby Dick comporta capítulos "líricos", verdadeiros exemplos da prosa poética romântica, e "dramáticos", aos quais não faltam indicações cênicas e que vão desde o monólogo até a espécie de ópera carnavalesca que é o XL ("Meia-noite, castelo de proa"). Já o capítulo XXXII ("Cetologia"), apresenta uma curiosa taxonomia das baleias, classificadas "em três LVROS fundamentais (subdivididos em CAPÍTULOS)” (MELVILLE, 1972, p. 172).

7 Cf. a distinção entre ambigüidade e contradição operada por Marcel Dettiene em Os Mestres da Verdade na Grécia Arcaica (DETTIENE, 1988, p. 65-72).

8 Mas é notório o papel que a epopéia exerceu na formação e na sustentação ideológica da pólis grega.

9 Adotamos aqui, muito a contragosto, mas em consonância com a edição utilizada, a "tradução" do nome do velho capitão Ahab, que, a despeito dos motivos óbvios, parece-nos totalmente injustificável. Não obstante, cotejamos a referida edição, uma tradução de Péricles Eugênio da Silva Ramos, com a edição de 1952 da University of Chicago, parecendo-nos aquela, de um modo geral, bastante fiel ao texto original.

10 Mas também parcialmente endossada por uma leitura mais atenta como a de Leon Howard. (Cf. HOWARD, 1966, p. 38.)

11 No original, "chaos bewitched".

12 O que não significa que essa idéia possa subsumir aqueles elementos. Quando, por exemplo, um "sinal do Destino" surge na imagem dos "fogos-de-santelmo", estes são descritos como um "fogo pálido", dotado de uma "luz espectral" (MELVILLE, 1772, p. 589-590), ou seja, com características que remetem à falta de substância. Além disso, em vários momentos predomina a idéia de que é Acab quem conduz seu destino. Assim, quando as bússolas do navio são desreguladas por uma trovoada - fenômeno natural de conotações simbólicas bem conhecidas -, o capitão improvisa uma outra com a ponta de aço de uma lança, e, ao final da operação, vangloria-se junto à tripulação: "Confirmai com vossos olhos se Acab não é senhor da magnetita horizontal! O sol está a leste, e a bússula jura isso!" (HOMERO, 1996, p. 605.) E tampouco a hybris que se revela no "fatal orgulho" com que o velho pescador enuncia tais palavras pode subsumi-las: afinal, nada indica que a potência humana que elas celebram contenha, necessariamente, essa hybris.

13 O já citado capítulo XL ("Meia-noite, castelo de proa"), que vai da página 214 à 221. 
6. Referências

DETTIENE, Marcel. Os Mestres da Verdade na Grécia Arcaica. Rio de Janeiro: Jorge Zahar, 1988.

HOMERO. Odisséia. São Paulo: Cultrix, 1996.

HOWARD, Leon. Moby Dick. In AARON, Daniel et al. Panorama do romance americano. São Paulo/Lisboa: Fundo de Cultura, 1966.
LUKÁCS, Georg. Teoria do Romance. Lisboa: Editorial Presença, s/d.

MELVILLE, Herman. Moby Dick ou A baleia. São Paulo: Abril Cultural, 1972.

Recebido em 26/11/2003

Aprovado em 15/01/2004 